\title{
Optimization of 400kv Transmission Line Towers
}

\author{
M.Amala, V.Gokul, G.Salaiamuthavalli, K.G.Akshaya
}

\begin{abstract}
Paper Setup Electric power plays an important role in the life of the community and the development of various sectors of economy. Developing countries like India therefore give a high priority to power development programmes. Wind pressure on conductor, insulator and ground wire and the wind load on the tower has been arrived based on IS $802-1995$ by taking into consideration of the following factors like average height of the conductor above the ground, drag coefficient of conductor, insulator and ground wire, position of different panels, total surface area of members in each panels, height from C.G to the ground level. Different loading conditions like Reliability condition, safety, security and anti cascading condition will be considered in different aspects which will be used in analysis and design. This project deals with "optimization of $400 \mathrm{KV}$ double circuit transmission line towers" in which the design can be executed by using STAAD PRO. The design and optimization of the tower can be carried out by altering the tower base width. By altering the base width of the tower, the corresponding members, bracing sizes and material properties of the members are being changed for analyzing the economical section. Depending upon the modified tower base width, the member and bracing sizes are suitably provided for different effective base width trials so as finalize the output of economical modified base width tower. The best optimized tower can be determined and recommended for safety and economy of steel.
\end{abstract}

Keywords-Conductor, Ground wire, base width of tower, optimization.

\section{INTRODUCTION}

A tower or mast is a large skeleton structure, with a relatively small cross section which has a large ratio between height and maximum width. A tower is a freely standing self supporting structure fixed to the base or foundation.

Towers are generally made up of high tensile steel rods. Transmission line towers are classified based on circuits. They are Single circuit, double circuit and Multi circuit tower. The tower configuration is dictated by the number of circuit and clearance required for the transmission line and the clearance required for the ground or other obstructions within limits, various tower configurations can be developed and the designer should investigate all these to select the most economical one. The purpose of a transmission line tower is to support conductors carrying electrical power and one or two ground wires at suitable distances above the ground level and from each other.

Revised Manuscript Received on 14 September, 2019.

M.Amala, SRM Easwari Engineering College, Department of Civil Engineering, Ramapuram,Chennai,Tamil Nadu, India.

V.Gokul, SRM Easwari Engineering College, Department of Civil Engineering, Ramapuram,Chennai,Tamil Nadu, India.

G.Salaiamuthavalli,, SRM Easwari Engineering College, Department of Civil Engineering, Ramapuram,Chennai,Tamil Nadu, India.

K.G.Akshaya, SRM Easwari Engineering College, Department of Civil Engineering, Ramapuram,Chennai,Tamil Nadu, India.
The transmission line tower cost about 35 to 45 percent of the total cost of the transmission line. A transmission tower is a space frame and is a high order indeterminate structure.

\section{SCOPE OF THE STUDY}

The main objective of this is the Design of Optimization of $400 \mathrm{KV}$ Double circuit transmission line towers in which the base width of the transmission line tower is being altered. By altering the base width of the tower, the corresponding members, bracing sizes and material properties of the members are being changed for analyzing the economical section. Depending upon the modified tower base width, the member and bracing sizes are suitably provided for different effective base width trials so as finalize the output of economical modified base width tower. Thus the best optimized tower can be obtained.

The aim of the project is to design the best optimized tower in which it results in the economy of the steel. By adopting suitable base width this can be achieved. Thus finally the optimized tower is said to be cost wise effective and consumption of steel is reduced. The anticipated growth of electrical power and the transmission line tower programmes in the future is very great. Thus economical type of transmission line tower design is preferred. The different wind loading conditions, sag and tension calculations and the loads acting on the tower can be computed by using IS 802 . Thus $400 \mathrm{KV}$ Double circuit has to be designed properly with tower angle to ensure safety for different practical load combinations.

\section{IIIL BACKROUND STUDY}

Analysis and design of three legged and four legged tower and thus three legged tower results in $21.2 \%$ of saving of steel when compared to four legged tower. Y. M. GHUGAL, U.S. SALUMKHE (2011).

Comparison of tubular and angular section where tubular section results in $20.9 \%$ of saving of steel when compared with angular section VINAY R. B, RANJITH A, BHARATH A (2015).

Corrosion of transmission line tower and its rehabilitation in which if tower leg corrodes it has to be rectified or it may lead to collapse of tower. S.CHRISTIAN JOHNSON, G.S.THIRUGNANAM (2010).

Computer Aided analysis and structural optimization of transmission towers in which six different panels are considered for $132 \mathrm{kv}$ double circuit transmission line tower, so as to adopt suitable tower. MR. T.RAGHAVENDRA (2012).

Published By: 
Weight optimization of double circuit steel transmission line towers is compared by using staad pro and PSO algorithm. PSO algorithm shows better results compared to STADD PRO. R.NAGAVINOTHINI, C.SUBRAMANIAN (2015)

Upgrading of transmission line towers using diaphragm bracing system is analyzed using fem software. F.ALBERMANI, M.MAHENDRAN (2010).

Static and dynamic analysis of transmission line towers under seismic loads in which zone 1 and zone 2 is considered and it is compared. SIDDU KARTHIK CS, G.V. SOWJANYA (2015).

Analysis of single circuit transmission line towers is analyzed using staad pro and the results which are obtained shows that by using triangular base self-supporting tower will bring a saving of $9.23 \%$ in the weight of structural steel, and using square base guyed mast will lead to a saving of $39.96 \%$ in the structural steel. C. PREETI, K. JAGAN MOHAN (2013).

\section{METHODOLOGY}

In this study it deals with the study of $400 \mathrm{KV}$ Double circuit Transmission line towers. This involves the details of fixing the structural details of the tower. Adopting ground clearances for different height of the tower and also calculating the wind pressure which is acting on the conductor, ground wire and insulator. According the nature and type of the tower and its circuit, the conductor and ground wire which has to be adopted is selected. The sag and tension calculations of the conductor and ground wire can be calculated by the data which are provided for selection of the type of the conductor and the ground wire.

Modeling of the tower has to be done in Staad pro and the required properties have to be provided. Different loading conditions like Reliability condition, Security condition adopted for the conductor and ground wire, Safety condition and Anti cascading condition for the angle tower as well as broken wire condition is being considered for the analysis of the tower. Then the axial load acting on the member is taken and thus according to that loading suitable member size has to be adopted. Thus design has to be carried out for all the members of the tower.

Then different base width trials has to be made by increasing and decreasing the base width of tower by $1 \mathrm{~m}$ and thus the base width is said to be altered. The base width dimensions are $13.893 \mathrm{~m}, 14.893 \mathrm{~m}, 15.893 \mathrm{~m}, 16.893 \mathrm{~m}$, and $17.893 \mathrm{~m}$. From this the economical base width of the tower can be determined.

\section{DESIGN PARAMETERS}

$\begin{array}{ll}\text { Span } & =400 \mathrm{~m} \\ \text { Wind zone } & =5 \\ \text { Reliability condition } & =1 \\ \text { Terrain category } & =1 \\ \text { Design wind speed } & =36.364 \mathrm{~m} / \mathrm{sec} . \\ \text { Wind Pressure on Conductor } & =185.063 \mathrm{~kg} / \mathrm{m}^{2}\end{array}$

$$
\begin{array}{ll}
\text { Wind Pressure on ground wire } & =230.007 \mathrm{~kg} / \mathrm{m}^{2} \\
\text { Wind Pressure on insulator } & =232.386 \mathrm{~kg} / \mathrm{m}^{2} \\
\text { Total Height above G.L } & =44.130 \mathrm{~m}
\end{array}
$$

Thus wind pressure of conductor, ground wire and insulator can be calculated by knowing the values of drag coefficient of the conductor and ground wire, design wind speed, Terrain categories and gust response factor of conductor, ground wire and insulator.

\begin{tabular}{|c|c|c|}
\hline DESCRIPTION & CONDUCTOR & $\begin{array}{l}\text { GROUND } \\
\text { WIRE }\end{array}$ \\
\hline Name/ code & ACSR MOOSE & GSS \\
\hline Nominal size & $54 / 3.18+7 / 3.18$ & $7 / 3.66$ \\
\hline Diameter $(\mathrm{cm})$ & 3.177 & 1.098 \\
\hline Unit weight $(\mathrm{kg} / \mathrm{m})$ & 2.004 & 0.583 \\
\hline UTS (kg) & 16428 & 6975 \\
\hline $\begin{array}{l}\text { Cross sectional } \\
\operatorname{area}\left(\mathrm{cm}^{2}\right)\end{array}$ & 5.97 & 0.7365 \\
\hline $\begin{array}{l}\text { Co.eff. of linear } \\
\text { Expansion. }\left(/{ }^{0} \mathrm{c}\right)\end{array}$ & $1.935 \times 10^{-6}$ & $11.5 \times 10^{-6}$ \\
\hline $\begin{array}{l}\text { Final modulus of } \\
\text { elasticity }\left(\mathrm{kg} / \mathrm{cm}^{2}\right)\end{array}$ & $7.03 \times 10^{5}$ & $1.933 \times 10^{6}$ \\
\hline Min. Température. & $10^{\circ} \mathrm{c}$ & $10^{\circ} \mathrm{c}$ \\
\hline $\begin{array}{l}\text { Every day } \\
\text { temperature. }\end{array}$ & $32^{\circ} \mathrm{c}$ & $32^{0} \mathrm{c}$ \\
\hline Max. Température. & $75^{\circ} \mathrm{c}$ & $53^{0} \mathrm{c}$ \\
\hline $\begin{array}{l}\text { Max. Wind pressure } \\
\left(\mathrm{kg} / \mathrm{m}^{2}\right)\end{array}$ & 185.063 & 230.007 \\
\hline Basic span(m) & 400 & 400 \\
\hline
\end{tabular}

\section{CONDUCTOR AND GROUND WIRE DETAILS $\&$ RESULTS}




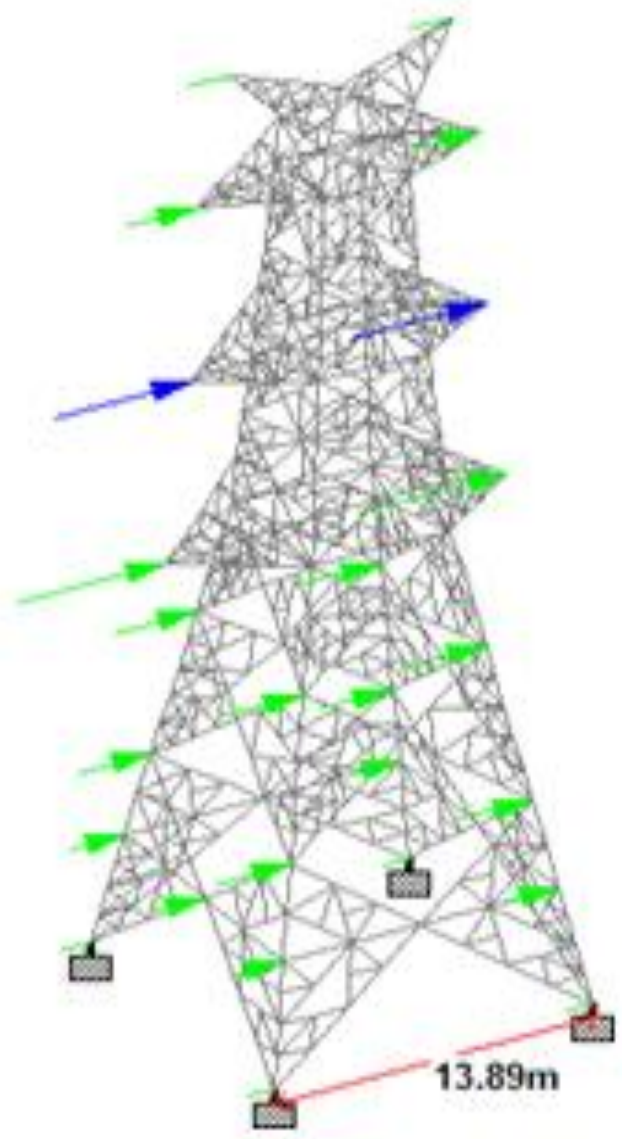

\begin{tabular}{|c|c|c|}
\hline PROFILE & LENGTH (M) & WEIGHT (KG) \\
\hline $200 \times 200 \times 25$ & 38.39 & 2837.021 \\
\hline $200 \times 200 \times 24$ & 28.95 & 2058.345 \\
\hline $200 \times 200 \times 20$ & 21.73 & 1303.8 \\
\hline $200 \times 200 \times 16$ & 33.46 & 1622.81 \\
\hline 130x130x10 & 32.76 & 645.372 \\
\hline $120 \times 120 x 12$ & 181.27 & 3915.432 \\
\hline $120 \times 120 \times 12$ & 366.58 & 7918.128 \\
\hline $120 \times 120 \times 8$ & 144.80 & 2128.56 \\
\hline $110 \times 110 \times 10$ & 70.22 & 1165.652 \\
\hline $110 \times 110 \times 10$ & 171.19 & 2841.754 \\
\hline $100 \times 100 \times 8$ & 93.13 & 1126.873 \\
\hline $100 \times 100 x 8$ & 35.69 & 431.849 \\
\hline $100 \times 100 \times 6$ & 11.84 & 108.928 \\
\hline $90 \times 90 \times 6$ & 282.68 & 2317.976 \\
\hline $80 \times 80 \times 6$ & 36.27 & 264.771 \\
\hline $75 \times 75 \times 6$ & 91.92 & 625.056 \\
\hline $60 \times 60 \times 4$ & 123.87 & 458.319 \\
\hline $50 \times 50 \times 4$ & 188.75 & 566.25 \\
\hline $45 \times 45 \times 3$ & 111.85 & 234.885 \\
\hline $40 \times 40 \times 3$ & 106.12 & 191.016 \\
\hline TOTAL & & 32498.026 \\
\hline
\end{tabular}

\begin{tabular}{|l|l|l|}
\hline PROFILE & LENGTH (M) & WEIGHT (KG) \\
\hline 200X200X24 & 38.71 & 2752.281 \\
\hline $200 X 200 X 24$ & 29.19 & 2075.409 \\
\hline 200X200X20 & 21.91 & 1314.6 \\
\hline $200 X 200 X 16$ & 33.46 & 1622.81 \\
\hline $130 X 130 X 10$ & 32.76 & 645.372 \\
\hline $130 X 130 X 8$ & 71.11 & 1130.649 \\
\hline $120 X 120 X 12$ & 181.27 & 3915.432 \\
\hline $120 X 120 X 12$ & 366.58 & 7918.128 \\
\hline $120 X 120 X 8$ & 144.80 & 2128.56 \\
\hline $110 X 110 X 8$ & 179.37 & 2403.558 \\
\hline $100 X 100 X 8$ & 35.69 & 431.849 \\
\hline $100 X 100 X 7$ & 95.87 & 1025.809 \\
\hline $100 X 100 X 6$ & 11.84 & 108.928 \\
\hline $90 X 90 X 6$ & 293.54 & 2407.028 \\
\hline $75 X 75 X 6$ & 91.92 & 625.056 \\
\hline $80 X 80 X 6$ & 36.27 & 264.771 \\
\hline $60 X 60 X 4$ & 124.64 & 461.168 \\
\hline $50 X 50 X 4$ & 193.82 & 581.46 \\
\hline $45 X 45 X 3$ & 111.85 & 234.885 \\
\hline $40 X 40 X 3$ & 106.12 & 191.016 \\
\hline TOTAL & & 32238.769 \\
\hline
\end{tabular}


BASE WIDTH 15.893M

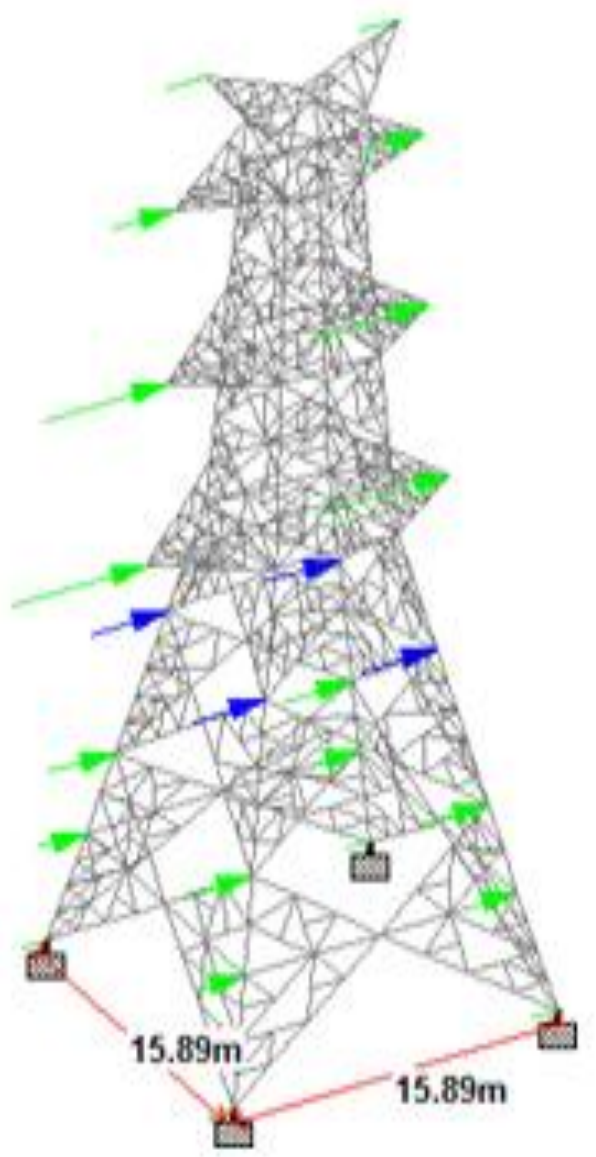

\begin{tabular}{|c|c|c|}
\hline PROFILE & LENGTH (M) & WEIGHT (KG) \\
\hline $200 \times 200 \times 24$ & 39.07 & 2777.877 \\
\hline $200 \times 200 \times 24$ & 29.46 & 2094.606 \\
\hline $200 \times 200 \times 20$ & 22.12 & 1327.2 \\
\hline $200 \times 200 \times 16$ & 33.46 & 1622.81 \\
\hline 130X130X10 & 32.76 & 645.372 \\
\hline $150 \times 150 \times 10$ & 181.27 & 4151.083 \\
\hline $120 \times 120 X 12$ & 366.58 & 7918.128 \\
\hline $120 X 120 X 8$ & 72.02 & 1058.694 \\
\hline $120 X 120 X 8$ & 144.80 & 2128.56 \\
\hline $100 X 100 \times 8$ & 187.66 & 2270.686 \\
\hline 100X100X8 & 35.69 & 431.849 \\
\hline $100 \times 100 \times 7$ & 98.66 & 1055.662 \\
\hline 100X100X6 & 11.84 & 108.928 \\
\hline $90 \times 90 \times 6$ & 304.57 & 2497.474 \\
\hline $80 \times 80 X 6$ & 36.27 & 264.771 \\
\hline $75 \times 75 \times 6$ & 91.92 & 625.056 \\
\hline $60 \times 60 \times 4$ & 125.51 & 464.387 \\
\hline $50 \times 50 \times 3$ & 199.03 & 457.769 \\
\hline $45 \times 45 \times 3$ & 111.85 & 234.885 \\
\hline $40 \times 40 \times 3$ & 106.12 & 191.016 \\
\hline \multicolumn{2}{|l|}{ TOTAL } & 32326.813 \\
\hline
\end{tabular}

BASE WIDTH 16.893M

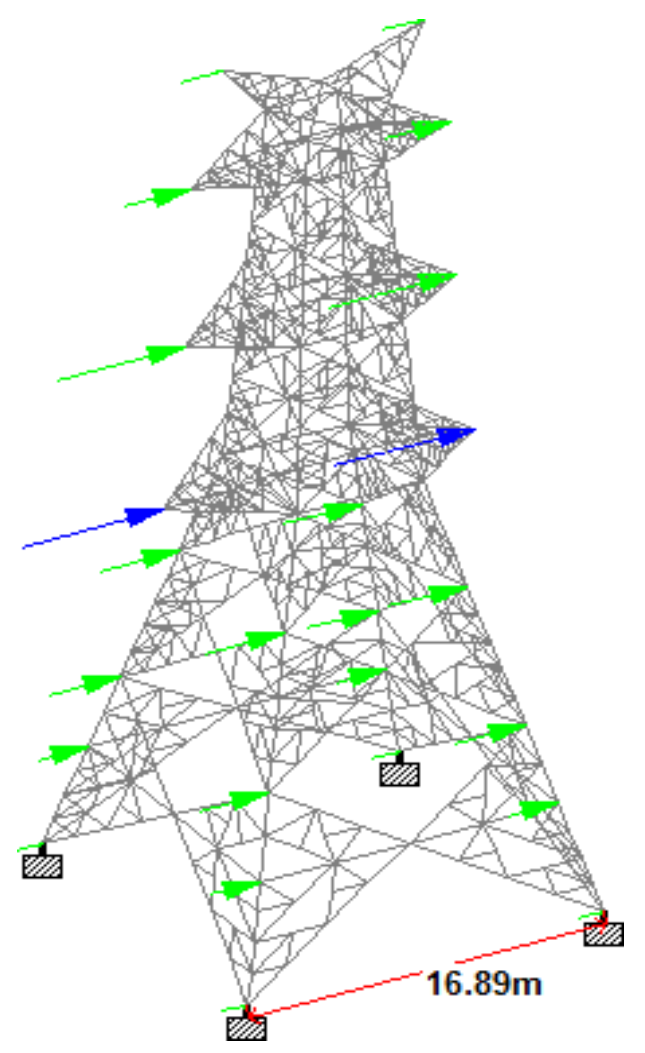

\begin{tabular}{|c|c|c|}
\hline PROFILE & LENGTH (M) & WEIGHT (KG) \\
\hline $200 \times 200 \times 24$ & 39.46 & 2805.606 \\
\hline $200 \times 200 \times 24$ & 29.76 & 2115.936 \\
\hline $200 \times 200 X 20$ & 22.34 & 1340.4 \\
\hline $200 \times 200 \times 16$ & 33.46 & 1622.81 \\
\hline $130 \times 130 X 10$ & 32.76 & 645.372 \\
\hline $150 X 150 X 10$ & 181.27 & 4151.083 \\
\hline 120X120X12 & 366.58 & 7918.128 \\
\hline $120 X 120 X 8$ & 144.80 & 2128.56 \\
\hline $110 X 110 X 8$ & 72.94 & 977.396 \\
\hline $100 X 100 X 8$ & 196.02 & 2371.842 \\
\hline $100 \mathrm{X} 100 \mathrm{X} 8$ & 35.69 & 431.849 \\
\hline 100X100X6 & 11.84 & 108.928 \\
\hline $80 \times 80 \times 10$ & 101.49 & 1197.582 \\
\hline $90 \times 90 \times 6$ & 315.70 & 2588.74 \\
\hline $80 \times 80 \times 6$ & 36.27 & 264.771 \\
\hline $75 \times 75 \times 6$ & 91.92 & 625.056 \\
\hline $60 \times 60 \times 4$ & 126.37 & 467.569 \\
\hline $50 \times 50 \times 3$ & 204.27 & 469.821 \\
\hline $45 \times 45 \times 3$ & 111.85 & 234.885 \\
\hline $40 \times 40 \times 3$ & 106.12 & 191.016 \\
\hline \multicolumn{2}{|l|}{ TOTAL } & 32657.35 \\
\hline
\end{tabular}

Published By:

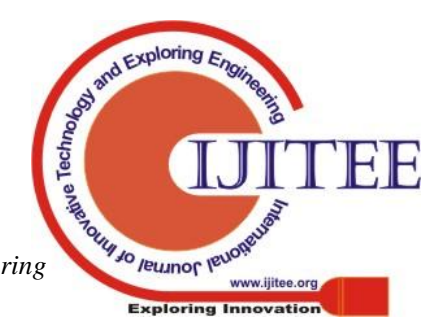




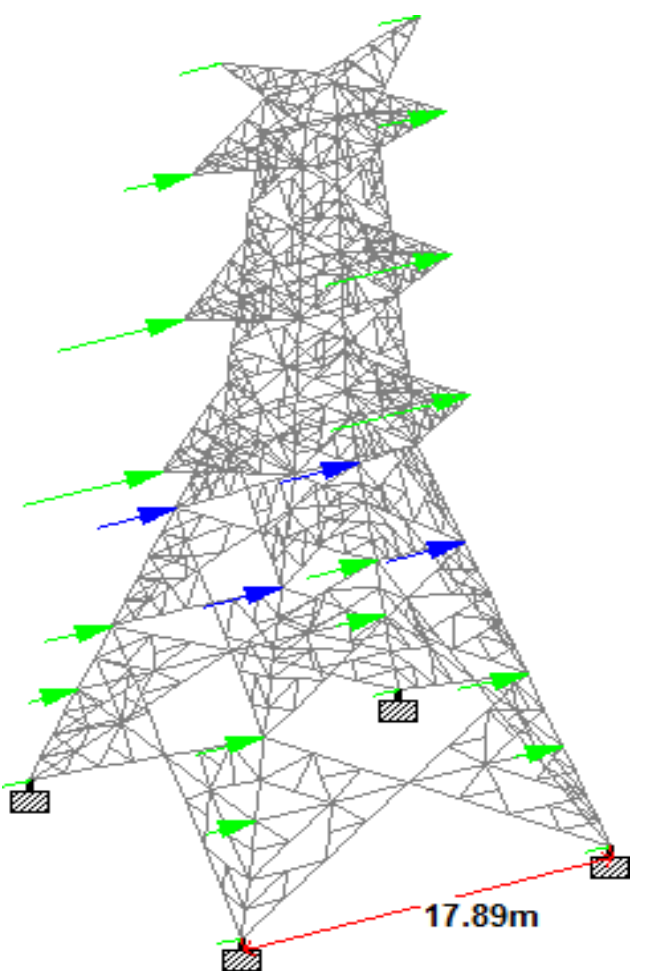

\begin{tabular}{|c|c|c|}
\hline PROFILE & LENGTH (M) & WEIGHT (KG) \\
\hline $200 \times 200 \times 24$ & 39.89 & 2836.179 \\
\hline $200 \times 200 X 24$ & 30.08 & 2138.688 \\
\hline $200 \times 200 \times 20$ & 22.58 & 1354.8 \\
\hline $200 X 200 X 16$ & 33.46 & 1622.81 \\
\hline $130 X 130 X 10$ & 32.76 & 645.372 \\
\hline $150 X 150 X 10$ & 181.27 & 4151.083 \\
\hline $120 X 120 X 12$ & 366.58 & 7918.128 \\
\hline 120X120X8 & 144.80 & 2128.56 \\
\hline $100 \mathrm{X} 100 \mathrm{X} 8$ & 35.69 & 431.849 \\
\hline $100 X 100 X 7$ & 204.51 & 2188.257 \\
\hline $100 \times 100 \times 6$ & 11.84 & 108.928 \\
\hline 100X100X6 & 104.36 & 960.112 \\
\hline $90 \times 90 \times 10$ & 73.87 & 989.858 \\
\hline $90 \times 90 \times 6$ & 327.08 & 2682.056 \\
\hline $80 \times 80 \times 6$ & 36.27 & 264.771 \\
\hline $75 \times 75 \times 6$ & 91.92 & 625.056 \\
\hline $60 \times 60 \times 4$ & 127.40 & 471.38 \\
\hline $50 \times 50 \times 3$ & 209.60 & 482.08 \\
\hline $45 \times 45 \times 3$ & 111.85 & 234.885 \\
\hline $40 X 40 X 3$ & 106.12 & 191.016 \\
\hline \multicolumn{2}{|l|}{ TOTAL } & 32425.872 \\
\hline
\end{tabular}

\section{COMPARISON OF BASE WIDTH OF TOWER}

\begin{tabular}{|l|l|}
\hline BASE WIDTH & WEIGHT (MT) \\
\hline $13.893 \mathrm{~m}$ & $32.4980 \mathrm{MT}$ \\
\hline $14.893 \mathrm{~m}$ & $32.2387 \mathrm{MT}$ \\
\hline $15.893 \mathrm{~m}$ & $32.3268 \mathrm{MT}$ \\
\hline $16.893 \mathrm{~m}$ & $32.6573 \mathrm{MT}$ \\
\hline $17.893 \mathrm{~m}$ & $32.4258 \mathrm{MT}$ \\
\hline
\end{tabular}

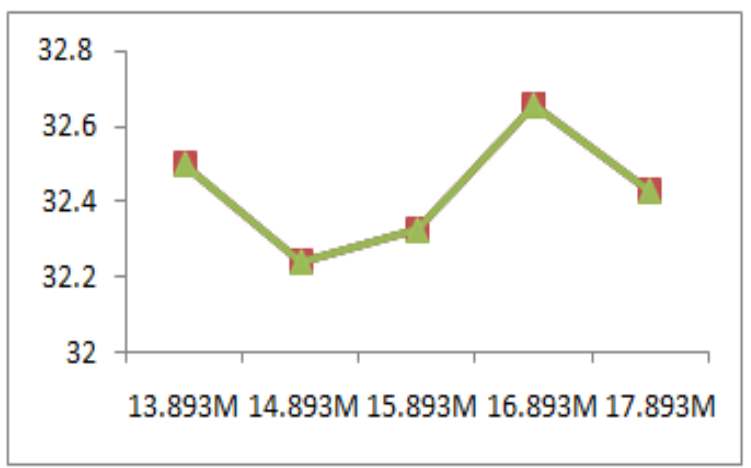

\section{CONCLUSIONS}

Different base width of tower has been calculated. The base width of $14.893 \mathrm{~m}$ has 32.2387 MT which is said to be economical. Thus it results in economy in steel when compared to other base width. Thus the base width of $14.893 \mathrm{~m}$ is said to be economical optimized tower.

\section{REFERENCES}

1. Y. M. Ghugal \& u.s. Salumkhe (2011) "analysis and design of three and four legged $400 \mathrm{kv}$ steel transmission line towers", international journal of earth science and engineering, issn 0974 - 5904, volume 04, no 6, spl pp 691-694.

2. Vinay r.b, ranjith a \& bharath a (2015) "optimization of transmission line towers-p delta analysis" international journal on innovative research in science engineering and technology, volume 3 , issue 7 .

3. S.christian johnson, g.s. Thirugnanam (2010) "corrosion of transmission line tower foundation and its rehabilitation", international journal of civil and structural engineering, issn 0976 - 4399, volume 1 , no 1.

4. T. Raghavendra (2012) "computer aided analysis and structural optimization of transmission line tower" international journal of advanced engineering technology, vol. 3 , issue 3 .

5. R.nagavinothini \& c.subramanian (2015) "weight optimization of double circuit steel transmission line tower using pso algorithm", international journal of science engineering and technology Research, volume 4, issue 2.

6. F.albermani \& m. Mahendran (2010) "upgrading of transmission tower using diaphragm bracing system", international journal of civil engineering volume 2 .

7. Siddu karthik cs \& g.v. Sowjanya (2015) "static and dynamic analysis of transmission towers under seismic loads", international journal of engineering research and technology issn $2278-0181$, volume 4 , issue 8 .

Published By: 
8. C. Preeti \& k. Jagan mohan (2013) presented a paper on "analysis of transmission towers with different configurations", jordan journal of civil engineering, volume 7 , no 4 .

9. I.s. 802 part $1 \mathrm{sec} 1$ (1995) "code of practice for use of structural steel in overhead transmission line towersmaterials and loads".

10. i.s. 802 part $2 \mathrm{sec} 1$ (1995) "code of practice for use of structural steel in overhead transmission line towerspermissible stresses"

\section{AUTHORS PROFILE}

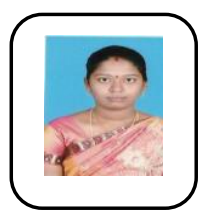

Mrs. M.Amala, M.E, Assistant Professor, Department of civil Engineering, Easwari Engineering College. Ramapuram, Chennai - 89, India

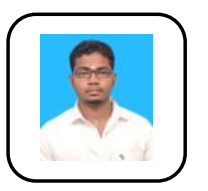

Mr. V.Gokul, M.Tceh, Assistant Professor, Department of civil Engineering, Easwari Engineering College. Ramapuram, Chennai - 89, India.

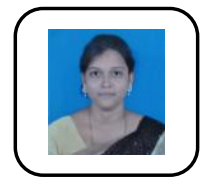

Mrs. G.Salaiamuthavalli , M.E, Assistant Professor, Department of civil Engineering, Easwari Engineering College. Ramapuram, Chennai - 89, India

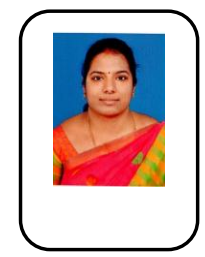

Mrs.K.G.Akshaya,M.E,Assistant Professor, Department of civil Engineering, Easwari Engineering College. Ramapuram, Chennai - 89, India. 